\title{
Impact of Intellectual Property Rights on the National Science System
}

\author{
Joseph Straus* \\ "Science, like nothing else among the institutions of mankind, \\ grows like a weed every year. Art is subject to arbitrary fashion, \\ religion is inwardly focused and driven only to sustain itself, \\ law shuttles between freeing us and enslaving us." \\ K.B. Mullis (Nobel Laureate for Chemistry 1993)
}

\begin{abstract}
After using the 2020 developments of the COVID-19 vaccines as an example of successful cooperation between academia, industry and government for supporting research and translating its results into innovations assisted by patents, the article turns to the national science systems. First, it addresses the pioneering role of the 1945 "Science the Endless Frontier", the Magna Carta of American Science and its patent policy. Retraced are the subsequent US developments revealing a gradual turn from incentivizing knowledge and technology transfer from government funded institutions to industry by allowing it only in the form of non-exclusive licenses, to imposing the public research sector an obligation to commercialize its research results by allowing exclusive licenses and assignments of intellectual property rights to private business. This all by recognizing and preserving academic freedom and inquiry. Next, it pays attention to developments in countries where legislators followed overall the US model. Finally, the contribution discusses the intellectual property rights system in the light of the specific needs of academic researchers.
\end{abstract}

Key words: University-Industry-Government Relations - Intellectual Property Rights and National Science Systems

\section{Introduction}

Seldom, if ever in peace times, have events such as those characterizing the year 2020, in a more impressive way demonstrated the importance of the so-called "Triple Helix" Alliance for the wellbeing of the society of the globe. The notion of the "Triple Helix" Alliance stands for "a spiral model

\footnotetext{
${ }^{*}$ Dr. jur., Dres. jur. h.c., Professor of Law (University of Munich and University of Ljubljana), Emeritus Director at the Max Planck Institute for Innovation and Competition, Munich. Foreign Member, Academy of Sciences and Arts of Bosnia and Herzegovina E-mail: j.straus@ip.mpg.de
} 
of innovation in terms of university-industry-government relations [is] required to capture the evolution of multiple linkages at different stages of the capitalization of knowledge". ${ }^{1}$ Only thanks to the successful and intensive university-industry-government interactions, it was possible, for the first time in history, to develop and put on the market new vaccines to fight the SARS 2 COVID-19 pandemic. The scientific and technological foundations for the vaccines of BioNTech-Pfizer, Moderna and Oxford-AstraZeneca, which were the first to receive marketing approval and enter the market, originate from the late 1980s-1990s.

First, the close international cooperation between publicly funded research institutions and biotech companies, relying on patents protecting their basic research inventions, ${ }^{2}$ generated the first therapeutics based on the recombinant DNA technology, such as human insulin, erythropoietin (EPO), granulocytecolony stimulating factors (GCSF) and others. Then, after some ten years, the intensive collaborative efforts within the Human Genome Project (HGP), an internationally supported public project (paralleled by Celera Genomics, a private effort), in 2001 culminated in the deciphering of the entire human genome. ${ }^{3}$ Whereas the Oxford-AstraZeneca researchers introduce into their vaccine double stranded DNA of the Coronavirus spike protein gene using another virus (an adenovirus) as vector ${ }^{4}$ - an approach developed in the 1990s - the BioNTech and Moderna vaccines store the instructions for building the spike protein in single-stranded RNA.

To end up with BioNTech-Pfizer and Moderna vaccines using messenger RNA as "vector", a change of paradigm, induced by research work on mRNA

\footnotetext{
${ }^{1}$ Leydesdorff \& Etzkowitz, Emergence of a Triple Helix of University-Industry-Government Relations, 1996:279-286, quoted from Leydesdorff \& Etzkowitz, The Future Location of Research: A Triple Helix of University-Industry-Government Relations II, 1996: 20-25. For a detailed discussion of the Triple Helix as a model for innovation studies, cf. Etzkowitz \& Leydesdorff, Universities and the Global Knowledge Economy: A Triple Helix of University-Industry-Government Relations, 1997:1-8 and Viale \& Etzkowitz, Third Academic Revolution: Polyvalent Knowledge; The "DNA" of the Triple Helix, 2005, accessible under https://www.researchgate.net/publication/242406526_Third_academic_revolution_polyvalent_knowledge_theDNA_of the_triple_helix - last visited February 9, 2021 and Leydesdorff, The Triple Helix: An Evolutionary Model of Innovations, 2000:243-255.

${ }^{2}$ Cf. e.g. Straus, Intellectual Property Rights and Bioeconomy, 2017:576-590 (pp. 580-582).

${ }^{3}$ Fraser, Editorial: A Genome to Celebrate, 2021:545; Jones \& Cook-Deegan, Complicated Legacies: The Human Genome at 20, 2021:564-569.

${ }^{4}$ Cf. Corum \& Zimmer, How the Oxford-AstraZeneca Vaccine Works, The New York Times of February 8, 2021 (https://www.nytimes.com/interactive/2020/health/oxford-astrazenecacovid-19-vaccine.html - last visited February 9, 2021).
} 
on both sides of the Atlantic, was necessary. However, while Katalin Karikó and Drew Weissman, the researchers who worked on mRNA at the University of Pennsylvania during the 1990s, have been praised as having been critical to the development of mRNA-based therapies, ${ }^{5}$ since they published a paper in $2005,{ }^{6}$ the name of Ingmar Hoerr, the European early pioneer in mRNA research is nowhere mentioned. Ingmar Hoerr who started his Ph.D. work in mid 1990s was convinced that RNA could be a platform for developing a multitude of therapies, from prophylactic vaccines to immunotherapies. Unlike Karikó and Weissman who reduced the antiviral response of mRNAs uridines with the modified versions, called pseudouridine and 5-methyluridine, i.e. by nucleosides and received a patent for their use in $2012,{ }^{7}$ Hoerr stabilized the mRNA by sequence modification. Since 1999, Hoerr has filed numerous patent applications, e.g. on June 5, 2001, i.e. 20 years ago, for "Pharmaceutical Composition Containing a Stabilized mRNA Optimized for Translation in its Coding Regions". ${ }^{8}$ Hoerr published his findings in 2000 in his doctoral thesis entitled "RNA Vaccine for the Induction of Specific Cytotoxic T-Lymphocytes (CTL) and Antibodies" and together with his group in the European Journal for Immunology. ${ }^{10}$ His discovery made it easy to use ribonucleic acid for the development of vaccines and immunotherapies. RNA vaccines can be produced in high amounts and have the same major advances as DNA vaccines but lack the potentially harmful effect of DNA integration into the genome. However, Ingmar Hoerr is not only the "seminal early mRNA pioneer", who has solved the problem of stabilizing the mRNA through a paradigm change. ${ }^{11}$ Dr. Hoerr also stands for entrepreneurial spirit and a remarkable enduring

\footnotetext{
${ }^{5} \mathrm{Cf}$. Keener, Just the Messenger: A New Class of Therapeutic Instruct the body to make its own drugs, 2018:1294-1300; Gaveria \& Kilic, A Network Analysis of COVID-19 mRNA Vaccine Patents, 2021:546-549; Fauci, The Story Behind COVID-19 Vaccines, 2021; Kolata, Kati Kariko Helped Shield the World From the Coronavirus, 2021.

${ }^{6}$ Karikó \& Buckstein \& Ni \& Weissman, Suppression of RNA Recognition by Toll-like Receptor: The Impact of Nucleoside Modification and the Evolution Origin of RNA, 2005:165175 , with references to some of their earlier publications.

${ }^{7}$ According to Keener, supra No. 6, p. 1299.

${ }^{8}$ US Patent 10188748 B2 (A1) of January 29, 2019, claiming as the first priority June 5, 2001 (application published on December 12, 2002).

${ }^{9} \mathrm{Cf}$. Wikipedia under Ingmar Hoerr.

${ }^{10}$ Cf. Hoerr \& Obst \& Rammensee \& Jung, In Vivo Application of RNA Leads to Induction of Specific Cytotoxic T-Lymphocytes and Antibodies, 2000:1-7.

${ }^{11}$ Kuhn emphasizes, "The scientific community is a supremely efficient instrument for maximizing the number and precision of the problem solved through paradigm change." (Kuhn, The Structure of Scientific Revolutions, 1970 (at p. 169)).
} 
energy necessary to translate an important basic research discovery into a commercially marketable and society benefitting product, e.g. a vaccine. In 2000, Ingmar Hoerr founded the successful biotech company CureVac, based in Tübingen, now working in co-operation with GlaxoSmithKline on a vaccine effective also against the Brazilian, UK and South African COVID 19 mutants. In an article published in 2017, Hoerr not only described in detail the challenging foundation of the company, the struggle to persuade and bring together public and private investors to provide the necessary funding, etc., but also emphasized that "valid preclinical data and ideally broad patents" were essential for the success of the company. ${ }^{12}$ It is difficult to understand that papers which report on CureVac's programs for mRNA-based influenza and malaria vaccines, supported by Bill \& Melinda Gates Foundation, or about CureVac first clinical trial of an mRNA vaccine against prostate cancer undertaken already in 2008, ${ }^{13}$ don't even mention Ingmar Hoerr, the founder of CureVac, or his seminal paper published in 2000!

When the development and marketing approval of a new vaccine, which requires tens of thousands of clinical tests and costs hundreds of millions or more Euros or Dollars, is at hand, universities, public research institutions and even successful biotech start-ups are in need of strong private and public allies. The financial risks are of such magnitude that even big pharmaceutical companies, as a rule, shy away from such endeavours if the government does not signal its readiness to support the project financially. In case of the development of Corona vaccines, even a pharmaceutical giant such as the US Company Merck \& Co., despite the already effected investment, gave up its efforts because of the setbacks it experienced. The International Federation of Pharmaceutical Manufacturers Association (IFPMA) estimates that expenditures of the pharmaceutical manufacturers branch for developing Corona vaccines and their production from private funds will amount to more than 10 billion US $\$$ by the end of 2021. However, public initial funding was also of key importance for the development of Corona vaccines. Without that funding, companies would have never taken up such a broad initiative. Most important by far was the funding provided by the US-Government's "Operation Warp Speed" action, which generated more than 12 billion US \$. The EU was much more modest. It will spend no more than few hundred millions of Euros for that purpose. Crucial for the incredible speed for the Corona vaccines

${ }^{12}$ Cf. Hoerr, A Successful Founder off the Beaten Path, 2017:900-903 (at 902, emphasis added).

${ }^{13}$ Cf. e.g. Keener, supra No. 6, p. 1298, reporting on CureVac but entirely ignoring Hoerr. 
development were not only the engagement of the best researchers and the financial support by government but also the prospect of a global market of an unprecedented size. Sales projected for 2021 are impressive: Pfizer $(\sim 15$ billion US \$), Moderna ( 12 billion US \$), BioNTech ( $\sim 8$ billion US \$), CureVac ( $\sim 5$ billion US \$) and AstraZeneca ( 4 billion US \$). ${ }^{14}$

The greatly appreciated and applauded success of the "Triple Helix" Alliance, which delivered the new vaccines to fight the Corona pandemic within an unbelievable one year, has, however, already been clouded. The reason being, the production capacities are lagging far behind the urgent demand, the enormous overall costs for the vaccination of the entire population, unaffordable for many if not most countries, and the prospect of profits which the vaccine producers, the beneficiaries of the multibillion initial public funding, can expect thanks to their patents. Not surprising, calls for compulsory patent pools, compulsory licenses, etc., to master the problems, and proposals for solving the problem by weakening patent protection followed. ${ }^{15}$ Indeed, surprising, however, was the May 5, 2021 decision of the US President Joe Biden to support a temporary waiver of Covid-19 vaccine patents, which provoked not only great concerns of the pharma industry, ${ }^{16}$ but has also been found neither appropriate nor productive by European leaders such as the German Chancellor Angela Merkel and the French President Emmanuel Macron. ${ }^{17}$

\section{National Science Systems}

(a) USA - The Pioneer

In 2020 the US celebrated the $75^{\text {th }}$ anniversary of what is regarded as the "Magna Carta of American Science", ${ }^{18}$ the Report "Science the Endless

\footnotetext{
${ }^{14} \mathrm{Cf}$. Benz \& Feldges, Ein Turbo für die Impfstoff-Hersteller: Lässt sich die Produktion von Corona-Vakzinen Beschleunigen?, 2021 (https://www.nzz.ch/wirtschaft/corona-impfungmoeglichkeiten-zur-beschleunigung-der-produktion-ld.1599788 - last visited February 8, 2021).

${ }^{15}$ Cf. e.g. Abbott \& Reichman, Facilitating Access to Cross-Border Supplies of Patented Pharmaceuticals: The Case of the COVID-19 Pandemic, 2020:535-561.

${ }^{16}$ Cf. e.g. Asgari \& Mancini \& Kuchler, Pharma Industry Fears Biden's Patent Decision Sets Dangerous Precedent, Financial Times, May 7, 2021, p. 3; Stacey \& Williams, Biden's Diplomatic Victory Blunts Pharma Lobby, Financial Times of May 10, 2021, p. 4.

${ }^{17}$ Cf. e.g. Peel, EU Leaders .Confront US over Vaccine Patent Waiver Demands, Financial Times of May 8, 2021, p.2.

${ }^{18}$ Thorp, Editorial: Science has always been Political, 2020:227.
} 
Frontier", which Vannevar Bush, Director of the Office of Science Research and Development, submitted to the President Harry Truman on July 25, 1945 (Report). ${ }^{19}$ This Report was the result of a 1944 request of President Franklin D. Roosevelt, who requested answers/ideas to four questions. They all centered around how best the results of the research work which Bush's Office so successfully conducted "in the utmost secrecy and carried on without public recognition of any kind; but its tangible results can be found in the communiques coming in from the battlefronts all over the world.", could be profitably employed in times of peace. This meaning, "for the improvement of national health, the creation of new enterprises bringing new jobs, and the betterment of the national standard of living." 20

As the Science Editor in Chief, Holden Thorp emphasizes, Bush's Report set out the rationale and structure of a system to fund science in the USA. ${ }^{21}$ As regards the rationale, the Report pointed out that "Science can be effective in the national welfare only as a member of a team, whether the conditions be peace or war. But, without scientific progress no amount of achievement in other directions can insure our health, prosperity, and security as a nation in the modern world." 22 Therefore, the Government should accept new responsibilities for promoting the flow of new scientific knowledge and the development of scientific talent of our youth. ${ }^{23}$ The Report recommended that a new agency for these purposes be established. That agency "should recognize that freedom of inquiry must be preserved and should leave internal control of policy, personnel, and the method and scope of research to the institutions in which it is carried on. It should be fully responsible to the President and through him to the Congress for its program." ${ }^{24}$ As the result of this Report, President Harry Truman on May 10, 1950 established the National Science Foundation, designed on the principle that scientists themselves should determine the course of fundamental research..$^{25}$

In the context of this contribution and in view of the ongoing debates on the impact of intellectual property rights, especially patents, on scientific progress and the translation of publicly funded research results to innovative

\footnotetext{
${ }^{19} \mathrm{https}$ ://www.nsf.gov/od/lpa/nsf50/vbush1945.htm - last visited February 3, 2021.

${ }^{20}$ President's Letter of November 17, 1944 (ibid p. 3, 4).

${ }^{21}$ Thorp, supra no. 11.

${ }^{22}$ The Report, p. 5.

${ }^{23}$ Ibid p. 7.

${ }^{24}$ Ibid p. 8.

${ }^{25}$ Cf. Gibson, Overseeing Innovation: 75 Years after Vannevar Bush's Impactful Report, Debate Continuous About Directing Science, 2020:258-259 (at p. 259).
} 
products and processes, the following statements in the "Science the Endless Frontier" Report seem of enduring relevance.

"The most important ways in which the Government can promote industrial research are to increase the flow of new scientific knowledge through support of basic research, and to aid in the development of scientific talent. In addition, the Government should provide suitable incentives to industry to conduct research, (a) by clarification of present uncertainties in the Internal Revenue Code in regard to the deductibility of research and development expenditures as current charges against net income, and (b) by strengthening the patent system so as to eliminate uncertainties which now bear heavily on small industries and so as to prevent abuses which reflect discredit upon a basically sound system. In addition, ways should be found to cause the benefits of basic research to reach industries which do not now utilize new scientific knowledge."26

"V. Patent Policy. - The success of the National Research Foundation in promoting scientific research in this country will depend to a very large degree upon the cooperation of organizations outside the Government. In making contracts with or grants to such organizations, the Foundation should protect the public interest adequately and at the same time leave the cooperating organization with adequate freedom and incentive to conduct scientific research. The public interest will normally be adequately protected if the Government receives a royalty-free license for governmental purposes under any patents resulting from work financed by the Foundation. There should be no obligation on the research institution to patent discoveries made as a result of support from the Foundation. There should certainly not be any absolute requirement that all rights in such discoveries be assigned to the Government, but it should be left to the discretion of the director and the interested Division whether in special cases the public interest requires such an assignment. Legislation on this point should leave to the Members of the Foundation discretion as to its patent policy in order that patent arrangements may be adjusted as circumstances and the public interest require." ${ }^{27}$

As result of the patent policy integrated into the "Science the Endless Frontier" Report, the US universities and publicly funded institutions engaged themselves actively in patenting. They received numerous patents, however, hardly ever commercially exploited. Since patents issued on publicly funded research results could be neither exclusively licensed, nor assigned to private businesses, their translation into innovative products and processes did not take place. By the end of 1970 s, of the 25.000 to 30.000 government owned

\footnotetext{
${ }^{26}$ Ibid, Summary (at p. 6).

${ }^{27}$ Ibid p. 30.
} 
patents, less than $5 \%$ were licensed. ${ }^{28}$ In order to overcome this economically unfavorable situation, in the 1980s the USA enacted several laws aimed at encouraging technology transfer of results from federally funded research undertaken at universities and academic research institutions. In 1980, the Bayh-Dole Act $^{29}$ introduced the possibility for private parties to retain patent rights via a "title in contractor" policy, i.e. small businesses and non-profit organizations, including universities could retain intellectual property rights to results from federally funded research. Also in 1980, the Stevenson-Wydler $\mathrm{Act}^{30}$ required that federal agencies administrating research establish an Office of Research and Technology Applications (ORTA) at all governmentoperated or contractor-operated laboratories with an annual budget of more than US \$ 20 Million. In 1986, the Federal Technology Transfer Act (FTTA) ${ }^{31}$ amended the Stevenson-Wydler Act by shifting the emphases in federal policy from one permitting technology transfer to one requiring the agencies act vigorously in working with industry to commercialize federally funded research. In the so-called Cooperative Research and Development Agreements (CRADAs) exclusive licensing terms were also allowed.

This legislative intervention of the US lawmaker had manifold and farreaching consequences. It has opened the way to fundamentally change the access to publicly funded research results since it not only encouraged, but in fact obliged universities and other publicly funded institutions to commercialize research results achieved by federal funds, i.e. make them proprietary as far as possible and, the Federal Government became a third player in the game. Although the overall social and economic impact of the Bayh-Dole Act and the other US legislative measures have often been questioned ${ }^{32}$, the undeniable fact is that the US universities and federally funded research institutions since the 1980s have played a key role as generator of new knowledge, as well as its translator into innovations. The annual statistics published by the US Association of University Technology Managers (AUTM) have demonstrated this since long. Its 2018 Licensing Activity Survey reveals that its members created 825 new products, formed 1.080 start-ups, filed 17.087

\footnotetext{
${ }^{28}$ Cf. Straus, supra no. 2 (at p. 581).

${ }^{29}$ Public Law 96-517.

${ }^{30}$ Public Law 96-480.

${ }^{31}$ Public Law 99-502.

${ }^{32}$ Cf., e.g. Mowery \& Nelson \& Sampath \& Ziedonis, The Growth of Patenting and Licensing by US Universities: An Assessment of the Effect of the Bayh-Dole Act of 1980, 2001:99-119; and as regards the critics Frangioni, The Impact of Greed on Academic Medicine and Patient Care, 2008:503-507.
} 
new US patent applications, executed 9.350 licenses and options and received 7.625 US patents. ${ }^{33}$ The total revenues of US universities from their licensing activities in 2018 amounted to US \$ 2.94 billion. Assuming the average $2 \%$ royalty rate, the academic technology was responsible for sales of products amounting to some US \$ 147 billion. ${ }^{34}$ Statistics for the years 20152019 reveal that universities have been very active if not even dominating in biotech patenting. Among the top 20 academic centers ranked by number of issued biotech patents, except for one - University of Tokyo ranked $17^{\text {th }}$ - all were American, with the University of California System (1.557 patents), Stanford University (658 patents), University of Texas System (531 patents), Massachusetts Institute of Technology (519 patents) and University of Pennsylvania (495 patents) in the top 5 ranks. ${ }^{35}$ Patenting activities are, however, expensive. In 2018 alone, US universities spent more than US \$ 425 million in patent related expenses. ${ }^{36}$

Patent statistics alone, however, do not yet represent a 'tangible outcome' of the increasing cooperation between federally funded research and industry since the adoption of the 1980s legislative measures. Most impressive in this regard are the aggregate data on the numbers of drugs developed from inventions, which Public Sector Research Institutions (PSRIs) had generated solely or jointly, protected by intellectual property rights specific to drugs, and subsequently transferred to a company through a commercial license. ${ }^{37}$ These data reveal that, between 1991 and 2006, 153 drugs were developed (e.g. also approved by the Federal Drug Administration (FDA)), from PSRIs research results, including 22 developed from the National Institutes of

\footnotetext{
${ }^{33}$ AUTM 2018 Licensing Activity Survey: A Survey of Technology Licensing and Related Activity for US Academic and Nonprofit Research Institutions, p. 4 (https://autm.net/ AUTM/media/SurveyReportsPDF/AUTM_FY2018_US_Licensing_Survey.pdf - last visited February 18, 2021).

${ }^{34}$ Cf. Dipanjan \& Gupta \& Turo, The Evolution of University Technology Transfer: By the Numbers, 2020 (https://researchgate.net/publication/340766806 - last visited February 20, 2021).

${ }^{35}$ Cf. for details Huggett \& Paisner, Biotech Patenting 2019, 2020:921-922.

${ }^{36}$ According to Dipanjan \& Gupta \& Turo, supra no. 34.

${ }^{37}$ As defined by Stevens \& Jensen \& Wyller \& Kilgore \& Chatterjee \& Rohrbaugh, The Role of Public-Sector Research in the Discovery of Drugs and Vaccines, 2011:535-541, at. p. 537. These authors emphasize that in most cases, the intellectual property was a patent or patent application, but that a few products have used proprietary biologic materials developed and licensed by the PSRI.
} 
Health's Intramural Research Program (NIH-IRP), ${ }^{38}$ for which patent applications were filed around 1985 (with one exception) and patents were granted between 1991 and 2007. ${ }^{39}$ The therapeutic areas of those 153 drugs were oncology (40), infectious disease (36), cardiology (12), immunology (6) and others (59)..$^{40}$ The remarkable impact that the drugs and biologics developed and patented by NIH alone had and still have on public health worldwide transpires from the fact that drugs and biologics still under license from NIH generated sales of US $\$ 4.7$ billion in 2010. In addition, sales for drugs and biologics for which patents had expired (that were no long under NIH licenses) were about US $\$ 2.2$ billion in 2010 . Thus, the total worldwide sales in 2010 for inventions of the NIH Intramural Program alone amounted to at least US \$ 6.9 billion. ${ }^{41}$ The instrumental role that NIH patents have played in achieving such impressive and beneficial 'tangible' results should be obvious.

\section{(b) Some Followers}

\section{(i) Japan}

The US 1980s statutory moves, which firmly embedded publicly funded academic research into the national innovation strategy, have not only inspired economists to direct their attention to the industry-academia links, ${ }^{42}$ but have

\footnotetext{
${ }^{38} \mathrm{Cf}$. Chatterjee \& Rohrbaugh, NIH Inventions Translate into Drugs and Biologics with High Public Health Impact, 2014:52-58, Table 3 (at p. 54).

${ }^{39} \mathrm{Ibid}$, Table 1 (at p. 53). The main applicant was the National Cancer Institute with 12 patent applications, respectively patents granted (Table 1 (at p. 53)).

${ }^{40}$ Ibid, Table 3 (at p. 54).

${ }^{41}$ Ibid (at pp. 56-57).

${ }^{42}$ Here only a selection can be referred to: Collier, Alan, Australian Framework for the Commercialization of University Scientific Research, 2007:51-68; Eun \& Lee \& Wu, Explaining the "University-run Enterprises" in China: A Theoretical Framework for University-Industry Relationship in Developing Countries and its Application to China, 2006:1329-1346; Abetti, University Incubators as Agents for Technology Transfer and Economic Growth: Case Studies in USA, Ukraine and Finland, 2006:308-337; Rubenstein \& Heisey \& King, Public Sector Technology Transfer Through Patents and Licensing: The Case of US Agriculture, 2006:401-420; Steenhuis \& Gray, The University as the Engine of Growth: An Analysis of How Universities can Contribute to the Economy, 2006:421-432; Walsh \& Cohen \& Cho, Where Excludability Matters, Material vs. Intellectual Property in Academic Biomedical Research, 2007:1184-2003; Chaves \& Moro, Investigating the Interaction and Mutual Dependence Between Science and Technology, 2007:1204-1220; Woolgar, New Institutional Policies for University-Industry Links in Japan, 2007:1261-1274 and D'Este, \& Patel, University-Industry Linkages in the UK: What are the Factors Underlying the Varity of Interactions with Industry? 2007:1295-1313.
} 
worked also internationally as an ignition for activities of many legislators. Those activities were all aimed at designing national innovation policies by taking into account the important role which academic research has to play in that context.

The closest follower was Japan, where the Diet in 1995 passed the Science and Technology Basic Law, in 1996 adopted the First and in 2001 the second Science and Technology Basic Plan. By the latter, a new Science and Technology Council, attached directly to the Cabinet Office was set up. ${ }^{43}$ In 1998, the Japanese Diet adopted the Act on the Promotion of Technology Transfer from Universities to Private Business. ${ }^{44}$ In executing the Science and Technology Basic Law, in October 2003, Japan transformed its Science and Technology Corporation (JST) into Japan Science and Technology Agency (JST) as an independent administrative institution. The Agency's task is to strengthen the infrastructure for the promotion of science and technology and implement initiatives set out in the Basic Law. ${ }^{45}$ In 2017, JST owned 3.604 patents worldwide and filed 75 patent applications. ${ }^{46}$ At its website, JST offers selected technologies for licensing, thereby making all information on the respective patents/patent applications online accessible. ${ }^{47}$ However, the results of the intense and long lasting efforts of the Japanese Government to promote university-industry cooperation aimed at incentivizing a smooth translation of academic research into innovative and marketable products and processes, so far achieved appear modest. The direct involvement of the government into the structure and functioning of universities, the limited acceptance of exclusive licensing of state funded research results to private business and the

\footnotetext{
${ }^{43}$ Cf. Edgington, The Japanese Innovation System: University-Industry Linkages, Small Firms and Regional Technology Centers, 2008:1-19 (at pp. 10 et seq). For policy initiatives promoting the university-industry ties in Japan see also Walsh \& Baba \& Goto \& Yasaki, Promoting University-Industry Linkages in Japan: Faculty Responses to a Changing Policy Environment, 2008:39-54; and Holroyd, Reinventing Japan Inc.: Twenty-First Century Innovation Strategies in Japan, 2008:21-38.

${ }^{44}$ Act No. 52 of May 6, 1998 (English translation WIPO) (https://www.wipo.int/edocs/ lexdocs/laws/en/jp/jp193en.pdf - last visited February 22, 2021). Cf. also Fujisue, Promotion of Academia-Industry Cooperation in Japan - Establishing the "Law of Promoting Technology Transfer from University to Industry", 1998:371-381.

${ }^{45}$ See https://www.jst.go.jp/EN/about/history.html - last visited February 20, 2021.

${ }^{46}$ See https://www.jst.go.jp/EN/about/jstdata.html - last visited February 20, 2021.

${ }^{47}$ See https://www.jst.go.jp/chizai/en/univ-ip/cips/licensing/details_01.html - last visited February $20,2021$.
} 
fact that universities are not the direct beneficiaries of licensing income, may be a combined reason for that situation. ${ }^{48}$

As in the US, also in Japan, universities are particularly active in patenting in the area of life sciences. In June of 2008, the Kyoto University, where the researchers were very successful in the area of induced pluripotent stem cells (iPS) technology, established the company iPS Academia Japan, Inc., aimed at licensing the iPS-cell technology. Since January 2016, iPS Academia has the status of an official organization for technology transfer under the 1998 Law for Promoting University-Industry Technology Transfer. ${ }^{49}$ In its portfolio, sourced not only from the Kyoto University rights but also from the rights of other Japanese Universities and even some foreign institutions, iPS Academia in 2012 had some 450 patent applications (some 125 patent families), among them some 200 on which patents were already granted by September 2016 in Japan, the USA, Europe and some other countries. ${ }^{50}$ According to its licensing guidelines, iPS Academia allows the not-for-profit organizations free use of its intellectual property for educational purposes, provided no commercial aim involved. As regards commercial entities, they, as a matter of principle, can only acquire non-exclusive licenses at reasonable terms. Since the changes of the guidelines of October 2015, however, in exceptional cases, where non-platform technologies are involved, commercial entities can acquire exclusive licenses. ${ }^{51}$ Until 2018, iPS Academia has granted 96 licenses to Japanese, 29 to US and 21 to European companies. Among them such pharmaceutical giants as Ajinomoto and Sumitomo from Japan and, e.g. Boehringer Ingelheim, Roche and Sanofi from Europe. ${ }^{52} 53$

\footnotetext{
${ }^{48}$ For a detailed analysis of Japanese developments until 2003, cf., Kneller, University-Industry Cooperation and Technology Transfer in Japan Compared with the United States: Another Reason for Japanese Malaise? 2003:329-449 (at pp. 347-449).

${ }^{49}$ See http://ips-cell.net/e/about/outline.html - last visited February 21, 2021.

${ }^{50} \mathrm{See}$ http://ips-cell.net/e/patent/ - last visited February 21, 2021.

${ }^{51}$ See http://ips-cell.net/e/license/policy.html - last visited February 21, 2021.

${ }^{52}$ See http://ips-cell.net/e/license/licensees.html - last visited February 21, 2021. Cf. also Straus, Patentierung und Kommerzialisierung im Bereich der Stammzellforschung, 2018:237276 (at pp. 244-245).

${ }^{53}$ As Japan, Korea and Taiwan, in the late 1990s, adopted similar science and technology basic laws. They allowed institutions of higher education the ownership in government financed research results and opened the way for their decentralized licensing. Cf. Chang \& Chen \& Yang \& Hua, Universities as Patent- and Licensing Income-Generating Institutions: A survey in Taiwan, 2008:290-309 (at p. 292).
} 


\section{(ii) China}

Not much later than Japan, the People's Republic of China, on May 15, 1996 adopted the Law on Promoting the Transformation of Scientific and Technological Achievements, which entered into force on October 1, 1996. An important amendment of that Law followed by the Order No. 32 of the President on August 29, 2015, which entered into force on October 1, 2015. ${ }^{54}$ As it transpires from its Article 1, the Law was developed for purposes of promoting the transformation of scientific and technological achievements into real productive forces, standardizing such transformation, accelerating scientific and technological progress, and promoting economic and social developments. Its 52 articles represent an all-encompassing and coherent legal framework aimed at successfully translating research findings also of "statemaintained research and development institutions and institutions of higher education", into innovative practice. These institutions can transfer their scientific achievements to enterprises or other organizations by assignment, license, investment as a trade-in and other means. They act based on own independent decisions, however, with prices to be determined by pricing in agreement, listing on the technology exchange market, auction, and other ways. In the case of pricing in agreement, they shall disclose the names of scientific and technological achievements and the proposed transaction prices in their entities. ${ }^{55} \mathrm{In}$ a number of provisions state defines measures such as to establish a public research and development platform, to provide technology integration, ${ }^{56}$ support the development for the incubation of science and technology enterprise as scientific and technological enterprise incubator and university science parks. ${ }^{57}$ Moreover, the Law sets forth that financial funds for the transformation of scientific and technological achievements be chiefly used as guidance funds, loan interest subsidies, subsidy funds, risk investments for the transformation, ${ }^{58}$ and that the state shall, in accordance with the provision of relevant tax laws and regulations, implement tax preference for the transformation activities. ${ }^{59}$

\footnotetext{
${ }^{54}$ PKULAW.COM [CLI Code]: CLI.1.256285(EN). Some Chinese authors call this law "the newly revised 'Bayh-Dole Act'," cf. e.g. Wang \& Xue \& Shi, Characteristics and Logical Framework of Chinese Universities' Response to the Newly Revised 'Bayh-Dole Act', 2021. ${ }^{55}$ Articles 17 and 18.

${ }^{56}$ Article 31.

${ }^{57}$ Article 32.

${ }^{58}$ Article 33.

${ }^{59}$ Article 34. According to the Articles 36 and 38, the state encourage insurance institutions to develop insurance products "commensurate with the characteristics of the." The state shall also encourage venture capital institutions to make investments in the respective projects.
} 
Under Article 43 of the Law, the income from the transformation, i.e. commercialization of research results, obtained by state-maintained R\&D institutions and institutions of higher education, "shall be totally retained thereto and be mainly used for science and technology research and development, achievement transformation, and other relevant work, after rewards and remunerations are granted to people who have made significant contributions to the completion and transformation of job-related scientific and technological achievements." Article 45 regulates the distribution of the proceeds from "commercialization" and the reward of the employees for the so-called jobrelated achievements, who significantly contributed to the transferred achievements, and provides the following interesting solutions:

"(1) Where a job-related scientific and technological achievement is assigned or licensed to others, not less than fifty percent of net income from assignment or license of such scientific and technological achievement shall be withdrawn.

(2) Where a job-related scientific and technological achievement is used as a trade-in in investment, not less than fifty percent of shares or capital contributions formed from such scientific and technological achievement shall be withdrawn. (3) Where a job-related scientific and technological achievement is implemented independently or in cooperation with others, not less than five percent of business profits from the implementation of the scientific and technological achievement shall be withdrawn consecutively for three to five years after the transformation and successful production thereof.

The method and amount of rewards and remunerations that state-maintained research and development institutions and institutions of higher education specify or agree upon with scientific and technical personnel shall comply with the criteria specified in item (1) to item (3) of the preceding paragraph.

State-owned enterprises and public institutions shall, in accordance with the provisions of this Law, include the expenditures of rewards and remunerations granted to people who have made significant contributions to the completion and transformation of the job-related scientific and technological achievements into their total wages in the current year, but the said expenditures shall not be subject to the restriction of their total wages in the current year and shall not be included into their total wage base."

Empirical data about the results of this Chinese legislation are not available. However, statistics about patent applications filed by Chinese universities and public research institutions such as the Chinese Academy of Sciences (CAS) clearly reveal that they are very active. For instance, in the area of artificial intelligence technologies, Chinese organizations make up 17 of the top 20 academic players in the world, with CAS ranking $17^{\text {th }}$ in the top 100 
of all applicants. Statistics for AI related patent applications reveal in general, high activity of universities and public research institutions. Among the top 500 of all applicants, 167 are academic institutions, of which 110 Chinese. ${ }^{60}$

\section{(c) Europe}

Although Europe also took note of the Bayh-Dole Act and other related US legislative developments of the 1980s and despite suggestions made to follow the US example, ${ }^{61}$ the European lawmakers, at the Community and the national level, until today resisted any Bayh-Dole type of legislation. Instead, they designed model agreements for industry-academic relationship. In its Recommendation 2008/416 of April 10, 2008 on the Management of Intellectual Property in Knowledge Transfer Activities, and Code of Practice for Universities and Other Public Research Organizations, ${ }^{6}{ }^{2}$ the Commission recommended that Member States, inter alia, ensure that all public research organizations (PROs) define knowledge transfer as a strategic mission. Further, encourage PROs to establish and publicize policies and procedures for the management of IP in line with the Code of Practice, support the development of knowledge transfer capacity and skills in PROs, raise the awareness and skills of students regarding IP, knowledge transfer and entrepreneurship, and promote the broad dissemination of knowledge, created with public funds. This all by taking steps to encourage open access to research results, while enabling, where appropriate, to protect related IP, etc. ${ }^{63}$

In its Knowledge Transfer Study, the EC Commission recognized that the European public research institutions were less effective in commercializing research results and generating invention disclosures, patent applications or license income as compared with the US counterparts. European publicly funded research institutions spent on average 3.3 times more research expenditures to earn $€ 1$ Million in license revenues than the US publicly funded research institutions. ${ }^{64}$ The Study found out that most European institutions

\footnotetext{
${ }^{60}$ Cf. WIPO Technology Trends 2019 - Artificial Intelligence, 2019:16-17; also Straus, Artificial Intelligence - Challenges and Chances for Europe, 2021:142-158 (at pp.146-147).

${ }^{61}$ Cf. Straus, The Present State of the Patent System in the European Union, 1997 (footnote 111 (at pp. 55 and 56) and Suggestion xiii (at p. 63)).

${ }^{62}$ Cf. EU Commission, OJ EC No. L 146, 2008:19.

${ }^{63}$ Cf. also Collins, European Tools up for Industry-Academic Collaborations, 2006:2-4, reporting on the so-called Lambert Agreement model contracts in the UK.

64 https://ec.europa.eu/research/innovation-union/pdf/knowledge_transfer_2010-2012_report.pdf - last visited February 25, 2021, pp. 128-129.
} 
involved in commercializing of academic research results were losing money, despite a vast pool of IP. Aimed at improving the efficiency of the transfer of intellectual property and technology by public sector research institutions into industry through R\&D contracts, licensing and spin-outs, the Commission launched the Call Capacity-Building in Technology Transfer. ${ }^{65}$ That Call resulted in the three years project Progress-TT - "Public Research Organization Growing Europe through best practice Solutions for Technology Transfer". Yet, Europe is still far behind the United States as regards knowledge and technology transfer from academia to industry. Nonetheless, institutions such as Oxford University Innovation (OUI), Oxford Nanopore Technologies, and the University College London Business from the UK, the German Max Planck Innovation and the French CERN are examples of successful commercialization of research results of their institutions. Numerous patents, licensing agreements and start-ups witness that success. ${ }^{66}$

\section{(d) Germany}

Inspired by the US legislative developments, which have narrowed the academic freedom of publicly funded researchers and their employers to publish and freely disseminate their research, the German legislator, in 2002, fundamentally revised the respective provision of the Act on Employee's Inventions. ${ }^{67}$ Based on the constitutional right of freedom of science and research of Article 5 (3) of the German Basic Law (Grundgesetz - Constitution), Section 42 (1) of the Act declared that inventions made by professors, lecturers and scientific assistants, in their capacity as such, at universities and higher schools of science shall be free inventions. Meaning that they belonged to their inventors without any limitations and thus could have been published or filed for a patent at their discretion. The changed Section 42 of the Act now sets forth that inventions of employees of universities and other institutions of higher education are, as far as the entitlement to them is concerned, in principle subjected to the same rules provided for under the Act for inventions of all other employees. However, contrary to the general rule, this group

\footnotetext{
65 https://ec.europa.eu/info/funding-tenders/opportunities/portal/screen/opportunities/topicdetails/cbtt-1-2014 - last visited February 25, 2021.

${ }^{66} \mathrm{Cf}$. the ALLEA Statement "The Need for Intellectual Property Rights Strategies at Academic Institutions" (https://allea.org/wp-content/uploads/2019/11/The_Need_for_IPR_Strategies_at_Academic_Institutions_ALLEA_2019-1.pdf - last visited February 25, 2021), 2019: $6-7$, with further references.

${ }^{67}$ Federal Official Journal 2002 I, 2002:414.
} 
of inventors has the right to disclose their "service inventions" within their teaching or research activities, provided they have timely (as a rule, 2 months in advance) notified their invention to the employer (Section 42 (1) no. 1). Moreover, in case the inventor decides not to disclose his invention in the course of his teaching and research activities, he is not obliged to notify the employer of his service invention at all. One further fundamental difference existing between service inventions of university personnel and those of all other employees concerns the reward the employer (i.e. university) has to pay to the inventor in case of exploitation of inventions he acquired. That reward has been fixed by the Statute at $30 \%$ of the income earned (Section 42 (4)), which is much higher than that calculated for other employee inventors. The Federal Government used several millions of Euros from the billions generated by auctions of the Universal Mobile Telecommunications System (UMTS) to finance the infrastructure necessary to enable universities to take up the knowledge and technology transfer task. 19 professional agencies for patenting and exploitation of publicly funded research were established and in 2002 started coaching 170 universities and 40 smaller research institutions. ${ }^{68}$ How successful the so-called "exploitation offensive" of the Federal Government has been is difficult to assess. Recently, criticism of unsatisfied faculties about their share in proceeds, even indicating that some professors use a "dummy" as applicant to circumvent their statutory obligation and uphold their established industry ties, came to the light. ${ }^{69}$

In a decision of September 18, 2007, ${ }^{70}$ the German Federal Supreme Court conceded, on the one hand, that the obligation of professors and other university personnel to defer for a certain period the publication of research results underlying an invention, does indeed affect the freedom of science, i.e. academic freedom. On the other hand, however, the Court held that the freedom of research and teaching does not require the ownership of exploitation rights in his research results attached to the professor. The Court, moreover, observed, that Article 5 (3) of the Basic Law does not only control individual rights but constitutes also a basic norm containing a value judgement regulating the relationship between science and the state. According to this basic norm, the state has to undertake appropriate organization and measures in

\footnotetext{
${ }^{68} \mathrm{Cf}$. the answer of the Federal Government of August 21, 2002 in the Bundestag (Federal Parliament), Drucksache 14/9874, p. 26.

${ }^{69} \mathrm{Cf}$. Technologietransfer kommt nicht in Schwung (unsigned), Handelsblatt of March 3, 2021, https://www.handelsblatt.com/politik/deutschland/verwertunsoffensive-der-bundesre...

${ }^{70}$ GRUR Int. 2008:251-254 (at 254) - Freedom of Publication.
} 
the area of publicly funded research in order to leave the fundamental right to the free scientific activity untouched to the extent possible taking into account other legitimate tasks of scientific institution and constitutional rights of others involved. In this context, the Court clarified that the respective tasks must constitute legal values of constitutional ranking, but held that fundraising of the university, including from the pool of patentable inventions of its personnel, relates to the operational capability of the university having such constitutional ranking. The new rule introduced in 2002, according to the understanding of the Court, is taking into account the fiscal interest of the state, to enable universities to gain financial means from the exploitation of their inventions. It further emphasized that raising funds from inventions of universities' employees was, in principle, appropriate to strengthen the economy of the university. In view of the lack of a novelty grace period in the German Patent Act, the Court further observed that in order to secure the legitimate interests of the university, it was necessary for the legislator to introduce a rule preventing a premature disclosure of the invention. Further, that as long as universities were not expected or requested to give up basic research, or to perform it to a limited extent only, and concentrate on specific projects better suited for commercial exploitation, this does not shift the research mandate of the university from a purpose free basic research to a research aimed at an effective commercial use. Thus, this does not violate the constitutional right to freedom of research and teaching. Such a rationale, the Court held, however, could not be inferred from Section 42 of the revised Employees' Inventions Act.

\section{Intellectual Property Rights}

\section{(a) General}

According to Article 1 (2) of the International Agreement on Trade Related Aspects of Intellectual Property Rights (TRIPS) of 1994, which has introduced protection standards mandatory for all Member States of the World Trade Organization (WTO), the term 'intellectual property' covers patents, copyright and related rights, trademarks, industrial designs, geographic indications, layout designs (topographies) of integrated circuits and undisclosed information. The common characteristic of all of these rights is that they all relate to intangible ubiquitous results of human creative endeavor. In the context at hand, and of particular importance for research activities of the academic community, are patents and copyrights. 
Patents relate to new, non-obvious and industrially applicable inventions, ${ }^{71}$ i.e. instructions on how to solve technical problems by technical means. Discoveries as such do not constitute patentable subject matter. However, applied discoveries, i.e. concrete technical teaching, and not the theoretical explanation given for its functioning, are in principle patent eligible. For instance, Article 3 (2) of the 1998 Directive 98/44/EC of the European Parliament and the Council on the Legal Protection of Biotechnological Inventions ${ }^{72}$ sets forth that: "Biological material which is isolated from its natural environment or produced by means of a technical process may be the subject of an invention even if it previously occurred in nature." This applies also to elements isolated from the human body, including the sequence or partial sequence of a gene (Article 5 (2) of the Directive). ${ }^{73}$

Copyrights relate to literary and artistic works, including every production in literary, scientific and artistic domains, whatever the mode or form of its expression may be. Copyright provides also protection for computer programs, whether in source or object code, as well as for compilations of data (Article 2 (1) of the Berne Convention for the Protection of Literary and Artistic Works of 1886 (last revised in 1971) in connection with Article 10 TRIPS).

Both patents and copyrights are exclusive rights limited in time. Patents, as a rule, are limited to 20 years calculated from the filing date. ${ }^{74}$ The term of copyright protection is at least the lifetime of the author and 50 years after his death or, if calculated on the basis other than the life of a natural person, no less than 50 years from the end of the calendar year of authorized publication, or, failing such authorized publication, within 50 years from the making of the work, or 50 years from the end of the calendar year of making. ${ }^{75}$ Apart

\footnotetext{
${ }^{71}$ Article 27 (1) TRIPS requires all WTO Member States to provide patents for any inventions, whether products or processes, in all fields of technology, provided that they are new, involve an inventive step (are 'non-obvious') and are capable of industrial application (are 'useful'). For details, especially for the exceptions allowed under Article 27 (2) and (3) TRIPS, see Straus, Implications of the TRIPS Agreement in the Field of Patent Law, 1996:160-215.

${ }^{72}$ OJ EC No. L 213/13 of August 30, 1998.

${ }^{73}$ For the specific problem of patenting human embryonic stem cells see Straus, Research, Exploitation and Patenting in the Area of Human Embryonic Stem Cells in Europe - A Case of Concern Causing Inconsistency, 2017:107-120.

${ }^{74}$ Article 33 TRIPS. In a number of countries, e.g. U.S.A., Japan and the Member States of the EU, in the case of pharmaceuticals and agrochemicals, an extension of the term based on a so-called Supplementary Protection Certificate (SPC) of up to 5 years can be achieved in order to compensate for the period of time necessary to get marketing approval.

${ }^{75}$ Article 7 (1) of the Berne Convention in connection with Article 12 TRIPS.
} 
from the term of protection, the two categories of intellectual property rights most important to the academic world differ also in a number of other aspects, of which only the following should be mentioned: copyright does not require any formalities to come into being, but protects the author, in principle, only against 'copying' but not against independent creations. It also relates to the form of expression only, i.e. does not protect the content of the creation. Patents in most patent laws, require costly formal patent-granting proceedings with an examination of patentability requirements. Patents are 'blocking rights', i.e. they are also effective against independent inventors, who have either not applied for a patent or have done so only with a later priority.

As an instrument of economic policy, intellectual property rights provide incentives for and reward a broad range of useful human creativity. In particular, they play a key role as incentive for and safeguard of the risky investment in R\&D. It is important to point out that intellectual property rights achieve their macro- as well as micro-economic effects only via market mechanisms, of which they form an important and even indispensable instrument. Not patents themselves, which secure their holders the exclusive rights of exploitation, reward inventors and inventions, but their success on the market place in competition with technical and economic alternatives. It is up to the intellectual property rights owners to seek such opportunities and to select the most promising ones. ${ }^{76}$ Because of these mechanisms, inherent to the intellectual property system, only the 1980s US legislative actions could synchronize activities of the public sector research institutions with private $R \& D$ activities and optimally exploit their potentials. Although the importance of intellectual property rights, especially patents, for quite obvious reasons very much depends on the specific branch of industry, and is highest rated in the field of pharmaceuticals, it has become apparent and generally accepted that these rights constitute an efficient and indispensable incentive for research and innovation. ${ }^{77}$

\footnotetext{
${ }^{76}$ Cf. Beier, Significance of the Patent System for Technical Economic and Social Progress, 1980:563-584 (at p. 563).

${ }^{77} \mathrm{Cf}$. the comprehensive analysis by Sherwood, Intellectual Property Rights and Economic Development, 1990:67; Mansfield, Intellectual Property, Technology and Economic Growth, in Rushing, 1990:17-30; von Hippel, The Sources of Innovation, 1988:47; Mowery \& Rosenberg, Technology and the Pursuit of the Economic Growth, 1989:72 and Cohen \& Merrill, Introduction, 2003:3.
} 


\section{(b) Specific Aspects}

For the impact the intellectual property rights, especially patents, have, or better should have on the work of academic researchers, it is essential that the intellectual property rights protection system adequately takes into account the needs resulting from their mission in the national innovation ecosystem.

As an important generator of patentable research results, the academe needs a legal environment in which it can optimally fulfill its primary mission, namely to generate new knowledge and to disseminate this knowledge widely in a timely manner, without losing proprietary rights in that knowledge. Thus, the patent system must broadly include into the subject matter eligible for protection all research results in the most advanced areas of science and technology. In other words, achievements in genomics, proteomics, stem cells technology, nanotechnology, computer implemented inventions, and e.g. in artificial intelligence technology, which meet the regular patentability requirements as a matter of principle should be patentable. Moreover, the patent system should provide for conditions in which the desired making available and disseminating research achievements does not automatically result in the loss of proprietary rights. Thanks to the mandatory publication of patent applications within 18 months from the filing/priority date and the requirement to disclose the invention in the patent application in a manner sufficiently clear and complete for it to be carried out by a skilled person, patents act decisively against secrecy in favor of early publication of research results and their dissemination. In order to prevent that any publication in a scientific journal, or any oral presentation in a conference, or public use of an invention, automatically results in a loss of any right to its exclusive exploitation, countries such as Australia, Brazil, Canada, Japan, the USA, and many others, provided in their patent laws for a so-called "grace period." The grace period rule provides for immunity against own publication of the applicant, if the application is filed within six or twelve months from the date of publication. ${ }^{78}$ Unfortunately, the European Patent Convention (EPC) and the patent laws of all of its contracting parties adopted with the Article 55 EPC a narrow "grace period" providing for relief in case the disclosure occurred as result of an evident abuse in relation to the applicant or his legal predecessor. The repeated attempts of the European academic community, for instance represented by the Federation of European Academies of Sciences and Humanities

\footnotetext{
${ }^{78}$ Cf. Straus, Grace Period and the European and International Patent Law, Analysis of Key Legal and Socio-Economic Aspects, 2001.
} 
(ALLEA) ${ }^{79}$ to amend the novelty standard and bring it in line with the academe friendly standards of European counterparts, have been in vain.

As far as the position of academe as a user of patented inventions of third parties is concerned, patents should not constitute a serious obstacle for them to as far as possible freely access the latest achievements of science and technology and use them for educational, experimental and research purposes. By exempting from the effects of a patent, inter alia, acts done for experimental purposes relating to the subject matter of the patented invention and the use of biological material for the purpose of breeding or discovering and developing other plant varieties, ${ }^{80}$ in Europe patent protection does not constitute an obstacle for further scientific and technological developments. For instance, the German Federal Supreme Court (BGH) and the German Federal Constitutional Court held that any experiment related to the subject matter of the patented invention pursuing the enhancement of knowledge, i.e. to obtain further research results, including finding further medical uses of a patented drug, eventually undertaken for commercial aims, does not infringe a patent. ${ }^{81}$

\section{Conclusions}

The developments which started in the 1980s in the US, and those which followed in other countries, as reported also in Germany, clearly reveal an evolutionary change in the basic understanding of academic freedom to the extent to which the results of academic research are publicly financed. The underlying understanding being that imagination and creativity constitute important national resources and that the intellectual property rights system facilitates and permits the dissemination of research results to the public, as well as their translation in innovative products and processes. Moreover, that

\footnotetext{
${ }^{79}$ Cf. e.g. ALLEA Statement on Grace Period, adopted in a Conference on 'Grace Period' in Kiev (https://www.allea.org/wp-content/uploads/2015/08/Statement_Grace-Period_Kiev. pdf - last visited March 3, 2021), convened by ALLEA and the National Academy of Science of Ukraine (NAS.).

${ }^{80}$ Article 27 (b) and (c) of the Agreement on a Unified Patent Court, OJ EC 2013/C 175/01 of 20.6.2013. Although this Agreement due to the Brexit problems has not yet entered into force, national patent laws of EU Member States provide already such limitations of the effect of a patent.

${ }^{81}$ Cf. BGH Decisions of July 11, 1995, [1997] IIC 01, 103 - Clinical Tests, and of April 17, 1997, [1998] R.P.C. 423 - Clinical Trials II, and Federal Constitutional Court of May 10, 2000, [2001] GRUR 43 - Klinische Versuche.
} 
an efficient management of publicly funded research results is in the public interest and involves intellectual property rights.

Thus, intellectual property rights play an important role in any national science system. However, even if optimally adapted to the needs of academic researchers, they are but one element among many, responsible for successful functioning of the national science system. The US "Science the Endless Frontier" Report made it clear already in 1947 that "Science can be effective in the national welfare only as a member of a team". In other words, together with other parts of the society. Apart from the indispensable financial support, the science system also needs adequate legal ramifications. Intellectual property system, being just one. The tax law, providing preferential treatment for investing in R\&D and for proceeds generated by research results, and rational regulatory provisions dealing with safety, or ethics, being others. As the US legislation of the 1980s and its followers in Japan and China demonstrate, nurturing of national science systems is a demanding and complex task, which requires great efforts from all three parts of the "Triple Helix Alliance" to make it successful. To paraphrase the Nobel Laureate Karry Banks Mullis, the inventor of the patented polymerase chain reaction (PCR), one of the technological pillars of the rDNA technology, whose words introduced this contribution, the law should avoid to either "free," or "enslave" science. The law should nurture science in a balanced way between the two extremes. Karry Mullis is probably right that science "grows like a weed every year", but weed also needs some fertile soil. One should never ignore the wise words of Sir Charles Carter: You cannot have a healthy science in a sick economy. ${ }^{82}$ Thus, a healthy economy is the soil the national science needs, and if properly nurtured, science can in return contribute to the health of the national economy.

\section{Literature}

Abbott, Frederick M. and Reichman, Jerome H. (2020). Facilitating Access to Cross-Border Supplies of Patented Pharmaceuticals: The Case of the COVID-19 Pandemic. JIEL, Vol. 23, p. 535-561

Abetti, Pierre A. (2006). University Incubators as Agents for Technology Transfer and Economic Growth: Case Studies in USA. Ukraine and Finland. Int. J. Technology Transfer and Commercialization, Vol. 5 (No. 4), p. 308-337

Act on the Promotion of Technology Transfer from Universities to Private Business Operators (Tentative translation) (1998) [Digital Edition]. Taken from https://www.wipo.int/ edocs/lexdocs/laws/en/jp/jp193en.pdf

\footnotetext{
${ }^{82}$ Sir Carter, Conditions for the Successful Use of Science, 1983: 1295-1298.
} 
Agreement on a Unified Patent Court, OJ EC 2013/C 175/01 (2013) [Digital Edition]. Taken from https://eur- lex.europa.eu/LexUriServ/LexUriServ.do?uri=OJ:C:2013:175:0001: 0040:EN:PDF

ALLEA Statement on Grace Period (2013) [Digital Edition]. Taken from https://www.allea. org/wp-content/uploads/2015/08/Statement_Grace-Period_Kiev.pdf

ALLEA Statement "The Need for Intellectual Property Rights Strategies at Academic Institutions" (2019) [Digital Edition]. Taken from https://allea.org/wp-content/uploads/2019/11/ The_Need_for_IPR_Strategies_at_Academic_Institutions_ALLEA_2019-1.pdf

Asgari, Nikou, Mancini, Donato Paolo and Kuchler, Hannah (2021). Pharma Industry Fears Biden's Patent Decision Sets Dangerous Precedent, Financial Times of May 7, 2021

AUTM 2018 Licensing Activity Survey: A Survey of Technology Licensing and Related Activity for US Academic and Nonprofit Research Institutions [Digital Edition]. Taken from https://autm.net/AUTM/media/SurveyReportsPDF/AUTM_FY2018_US_Licensing_Survey.pdf

Beier, Friedrich-Karl (1980). Significance of the Patent System for Technical Economic and Social Progress, IIC, Vol. 11, p. 563-584

Benz, Matthias and Feldges, Dominik (2021). Ein Turbo für die Impfstoff-Hersteller: Lässt sich die Produktion von Corona-Vakzinen Beschleunigen? [Digital Edition]. Taken from https://www.nzz.ch/wirtschaft/corona-impfung-moeglichkeiten-zur-beschleunigung-derproduktion-ld.1599788

Bush, Vannevar (1945). Science the Endless Frontier. [Digital Edition]. Taken from https:// www.nsf.gov/od/lpa/nsf50/vbush1945.htm.

Carter, Charles (1983), Conditions for the Successful Use of Science. Science Vol. 219 (No. 4590), p. 1295-1298

Chang, Yuan-Chieh, Chen, Ming-Huei, Yang, Phil Y. and Hua, Mingshua (2008). Universities as Patent- and Licensing Income-Generating Institutions: A survey in Taiwan. Int. J. Technology Management, Vol. 42 (No. 3), p. 290 - 309

Chatterjee, Sabarni K. and Rohrbaugh, Mark L. (2014). NIH Inventions Translate into Drugs and Biologics with High Public Health Impact. Nature Biotechnology, Vol. 32 (No. 1), p. $52-58$

Chaves, Catari V. and Moro, Sueli (2007). Investigating the Interaction and Mutual Dependence between Science and Technology. Research Policy, Vol. 36 (No. 8), p. 1204-1220

Cohen, Wesley M. and Merrill, Stephen A. (2003). Patents in the Knowledge Based Economy. Study of the National Research Council of the National Academies. The National Academic Press, Washington D.C.

Collier, Alan (2007). Australian Framework for the Commercialization of University Scientific Research. Prometheus, Vol. 25 (No. 1), p. 51-68

Collins, Luke (2006). European Tools Up for Industry-Academic Collaborations. Research Technology Management, Vol. 49 (No. 5), p. 2-4

Corum, Jonathan and Zimmer, Carl (2021). How the Oxford-AstraZeneca Vaccine Works [Digital Edition]. Taken from https://www.nytimes.com/interactive/2020/health/oxfordastrazeneca-covid-19-vaccine.html

D'Este, P. and Patel, Parimal (2007). University-Industry Linkages in the UK: What are the Factors Underlying the Varity of Interactions with Industry? Research Policy, Vol. 36, No. 8, p. $1295-1313$ 
Dipanjan, Nag, Gupta, Antara and Turo, Alex (2020). The Evolution of University Technology Transfer: By the Numbers [Digital Edition]. Taken from https://researchgate.net/ publication/340766806

EC Commission, Knowledge Transfer Study [Digital Edition]. Taken from https://ec.europa. eu/research/innovation-union/pdf/knowledge_transfer_2010-2012_report.pdf

Edgington, David W. (2008). The Japanese Innovation System: University-Industry Linkages, Small Firms and Regional Technology Centers. Prometheus, Vol. 26, (No. 1), p. 1-19

Etzkowitz, Henry and Leydesdorff, Loet (1997). Universities and the Global Knowledge Economy: A Triple Helix of University-Industry-Government Relations. Cassells Academic, p. 1-8

Eun, Jong-Hak, Lee, Keun and Wu, Guisheng (2006). Explaining the "University-run Enterprises" in China: A Theoretical Framework for University-Industry Relationship in Developing Countries and its Application to China. Research Policy, Vol. 35 (No. 9), p. 1329-1346

Fauci, Anthony S. (2021). The Story Behind COVID-19 Vaccines. Science, Vol. 372 (No. 6538), p. 109

Frangioni, John V. (2008). The Impact of Greed on Academic Medicine and Patient Care. Nature Biotechnology, Vol. 26, p. 503-507

Fraser, Claire M. (2021). Editorial: A Genome to Celebrate. Science, Vol. 371 (No. 6529), p. 545

Fujisue, Kenzo (1998). Promotion of Academia-Industry Cooperation in Japan - Establishing the "Law of Promoting Technology Transfer from University to Industry". Technovation, Vol. 18, (No. 6-7), p. 371-381

Gaveria, Mario and Kilic, Burcu (2021). A Network Analysis of COVID-19 mRNA Vaccine Patents. Nature Biotechnology, Vol. 39, p. 546-549

Gibson, Emily K. (2020). Overseeing Innovation: 75 Years after Vannevar Bush's Impactful Report, debate continuous about directing science. Science, Vol. 369 (No. 6501), p. 258-259

Hippel, Eric von (1988). The Sources of Innovation. Oxford University Press, Oxford

Hoerr, Ingmar, Obst, Reinhard, Rammensee, Hans-Georg and Jung, Günther (2000). In Vivo Application of RNA Leads to Induction of Specific Cytotoxic T-Lymphocytes and Antibodies. Eur J Immonol, Vol. 30 (No. 1), p. 1-7

Hoerr, Ingmar (2017). A Successful Founder off the Beaten Path. Nature Biotechnology, Vol. 35, (No. 10), p. 900-903

Holroyd, Carin (2008). Reinventing Japan Inc.: Twenty-First Century Innovation Strategies in Japan. Prometheus, Vol. 26 (No. 1), p. 21-38

Huggett, Brady and Paisner, Kathryn (2020). Biotech Patenting 2019. Nature Biotechnology, Vol. 38 (No. 8), p. 921-922

Jones, Kathryn M. and Cook-Deegan, Robert (2021). Complicated Legacies: The Human Genome at 20. Science, Vol. 371 (No. 6529), p. 564-569

Karikó, Katalin, Buckstein, Michael, Ni, Houping and Weissman, Drew (2005). Suppression of RNA Recognition by Toll-like Receptor: The Impact of Nucleoside Modification and the Evolution Origin of RNA. Immunity, Vol. 23 (No. 2) p. 165-175

Keener, Amanda B. (2018). Just the Messenger: A New Class of Therapeutic Instruct the Body to Make its Own Drugs, Nature Medicine, Vol. 24, p. 1294-1300 
Kneller, Robert (2003). University-Industry Cooperation and Technology Transfer in Japan Compared with the United States: Another Reason for Japanese Malaise? U. Pa. J. Int'1 Econ. L., Vol. 24 (No. 2), p. 329-449

Kolata, Gina (2021). Kati Karikó Helped Shield the World From the Coronavirus. The New York Times of April 8, 2021

Kuhn, Thomas S. (1970). The Structure of Scientific Revolutions, Second Edition, Enlarged, Vol. 2, No. 2, University of Chicago Press, Chicago/London

Leydesdorff, Loet and Etzkowitz, Henry (1996). The Future Location of Research: A Triple Helix of University-Industry-Government Relations II: EASST Review, Vol. 15 (No. 4), p. $20-25$

Leydesdorff, Loet and Etzkowitz, Henry (1996). Emergence of a Triple Helix of UniversityIndustry-Government Relations. Science and Public Policy, Vol. 23, p. 279-286

Leydesdorff, Loet (2000). The Triple Helix: An Evolutionary Model of Innovations. Research Policy, Vol. 29 (No. 2), p. 243-255

Mansfield, Edwin (1990). Intellectual Property, Technology and Economic Growth. Rushing, Francis W. and Ganz-Brown, Carol (eds.), Intellectual Property Rights in Science, Technology, and Economic Performance - International Comparisons (p. 17-30), Routledge, New York

Mowery, David C. and Rosenberg, Natan S. (1989). Technology and the Pursuit of the Economic Growth. Cambridge University Press, Cambridge

Mowery, David C., Nelson, Richard R., Sampath, Bhaven N. and Ziedonis, Arvids A. (2001). The Growth of Patenting and Licensing by US Universities: An Assessment of the Effect of the Bayh-Dole Act of 1980. Research Policy, Vol. 30 (No. 1), p. 99-119

OJ EC No. L 213/13 (1998) [Digital Edition]. Taken from https://eur-lex.europa.eu/LexUriServ/LexUriServ.do?uri=OJ:L:1998:213:0013:0021:EN:PDF

OJ EC No. L 146 (2008) [Digital Edition]. Taken from https://eur-lex.europa.eu/legal-content/EN/TXT/PDF/?uri=CELEX:32008H0416\&from=EN

Peel, Michael (2021). EU Leaders Confront US over Vaccine Patent Waiver, Financial Times of May 8, 2021, p. 2

Report "A Missed Opportunity - The Patent Saga" [Digital Edition]. Taken from http://www. whatisbiotechnology.org/exhibitions/milstein/patents

Rubenstein, Kelly D., Heisey, Paul W. and King, John L. (2006). Public Sector Technology Transfer Through Patents and Licensing: The Case of US Agriculture. Int. J. Technology Transfer and Commercialization, Vol. 5 (No. 4), p. 401-420

Sherwood, Robert M. (1990). Intellectual Property Rights and Economic Development. Westview Press, Boulder

Stacey, Kiran and Williams, Aime (2021). Biden's Diplomatic Victory Blunts Pharma Lobby. Financial Times of May 10, 2021, p. 4

Steenhuis, Harm-Jan and Gray, Denis O. (2006). The University as the Engine of Growth: An Analysis of How Universities can Contribute to the Economy. Int. J. Technology Transfer and Commercialization, Vol. 5 (No. 4), p. 421-432

Stevens, Ashley J., Jensen, Jonathan J., Wyller, Katrine, Kilgore, Patrick C., Chatterjee, Sabarni and Rohrbaugh, Mark L. (2011). The Role of Public-Sector Research in the Discovery of Drugs and Vaccines. New England Journal of Medicine, Vol. 364 (No. 6), p. $535-541$

Straus, Joseph (1996). Implications of the TRIPS Agreement in the Field of Patent Law. Beier, Friedrich-Karl and Schricker, Gerhard (Eds.), From GATT to TRIPS - The Agree- 
ment on Trade-Related Aspects of Intellectual Property Rights (p. 160-215.), Wiley VCH, Weinheim

Straus, Joseph (1997). The Present State of the Patent System in the European Union. Office for Official Publications of the European Communities, Luxembourg

Straus, Joseph (2001). Grace Period and the European and International Patent Law, Analysis of Key Legal and Socio-Economic Aspects. IIC-Studies, Vol. 20 C.H. Beck Publishers, Munich

Straus, Joseph (2017). Research, Exploitation and Patenting in the Area of Human Embryonic Stem Cells in Europe - A Case of Concern Causing Inconsistency. European Review, Vol. 25 (No. 1), p. 107-120

Straus, Joseph (2017). Intellectual Property Rights and Bioeconomy. JIPLP, Vol. 12 (No. 7), p. $576-590$

Straus, Joseph (2018). Patentierung und Kommerzialisierung im Bereich der Stammzellforschung. Zenke, Martin, Marx-Stölting, Lilian and Schickl, Hannah (Eds.), Stammzellforschung: Aktuelle wissenschaftliche und gesellschaftliche Entwicklungen. (p. 237276), Nomos, Baden-Baden

Straus, Joseph, Artificial Intelligence - Challenges and Chances for Europe (2021). European Review, Vol. 29 (No. 1), p. 142-158

Thorp, Holden H. (2020). Editorial: Science has always been Political. Science, Vol. 369 (No. 6501), p. 227

Viale, Riccardo and Etzkowitz, Henry (2005). Third Academic Revolution: Polyvalent Knowledge; The "DNA" of the Triple Helix [Digital Edition]. Taken from https://www. researchgate.net/publication/242406526_Third_academic_revolution_polyvalent_ knowledge_theDNA_of_the_triple_helix

Walsh, John P., Cohen, Wesley $\bar{M}$. and Cho, Charlene (2007). Where Excludability Matters, Material vs. Intellectual Property in Academic Biomedical Research. Research Policy, Vol. 36 (No. 8), p. 1184-2003

Walsh, John P., Baba, Yasunori, Goto, Akira and Yasaki, Yoshihito (2008). Promoting University-Industry Linkages in Japan: Faculty Responses to a Changing Policy Environment. Prometheus, Vol. 26 (No. 1), p. 39-54

Wang, Xiuqin, Xue, Lan and Shi, Dongbo (2021). Characteristics and logical framework of Chinese universities' response to the newly revised 'Bayh-Dole Act'. Studies in Science of Science [Digital Edition]. Taken from https://doi.org/10.16192/j.cnki.10032053.20201125.001 (only abstracts in English)

WIPO Technology Trends 2019 - Artificial Intelligence (2019) [Digital Edition]. Taken from. https://www.wipo.int/edocs/pubdocs/en/wipo_pub_1055.pdf

Woolgar, Lee (2007). New Institutional Policies for University-Industry Links in Japan. Research Policy, Vol. 36 (No. 8), p. 1261-1274 